\title{
PENGARUH MODEL PEMBELAJARAN KOOPERATIF NHT DAN STAD TERHADAP HASIL BELAJAR SIKAP SISWA SMA NEGERI 2 GERUNG
}

\author{
I. G. M. R. Aryana ${ }^{1}$, Agil Al Idrus ${ }^{2}$, Ahmad Harjono ${ }^{3}$ \\ ${ }^{1}$ Program Studi Pendidikan IPA Program Pascasarjana Universitas Mataram \\ ${ }^{2}$ Program Studi Pendidikan Biologi, FKIP, Universitas Mataram \\ ${ }^{3}$ Program Studi Pendidikan Fisika, FKIP, Universitas Mataram \\ J1.Majapahit No. 62 Mataram
}

\begin{abstract}
ABSTRAK: Penelitian ini bertujuan untuk mengetahui perbedaan hasil belajar sikap siswa antara kelompok siswa yang mendapatkan perlakuan model pembelajaran kooperatif NHT dan model pembelajaran kooperatif STAD pada pembelajaran biologi sistem pencernaan. Penelitian ini dilaksanakan di SMA Negeri 2 Gerung pada siswa kelas XI jurusan Ilmu Pengetahuan Alam semester genap tahun pelajaran 2014/2015. Penelitian ini merupakan penelitian kuasi eksperimen dengan menggunakan rancangan Type Between Group Design dengan Posttest Only Design. Populasi penelitian berjumlah 44 siswa terdiri atas dua kelas, dimana keseluruhan populasi dijadikan sebagai sampel penelitian. Melalui teknik simple random sampling ditentukan dua kelas eksperimen. Data yang diperoleh dianalisis dengan menggunakan analisis statistik deskriptif yaitu dengan menghitung rata-rata dari jawaban yang diberikan kemudian dinyatakan dalam bentuk angka persentase dari setiap pernyataan. Angka persentase yang menggambarkan sikap pada indikator: rasa ingintahu, tanggungjawab, dan disiplin diuji hipotesisnya menggunakan analisis uji-t dengan bantuan program SPSS versi 20 for Windows. Hasil penelitian menunjukkan bahwa tidak ada perbedaan hasil belajar sikap yang signifikan antara kelompok siswa yang menggunakan model pembelajaran kooperatif NHT dan model pembelajaran kooperatif STAD dimana diperoleh nilai $t_{\text {hitung }} \leq \mathrm{t}_{\text {tabel }}(\mathrm{p}>0.05)$ pada setiap indikator sikap.
\end{abstract}

Kata kunci: $\quad$ Model pembelajaran kooperatif NHT, STAD, hasil belajar sikap siswa.

ABSTRACT: This study aims to determine differences of student's attitude learning outcomes between groups of students who receive NHT cooperative learning model and STAD cooperative learning model treatment for biology digestive system learning. This research was conducted at SMAN 2 Gerung in class of XI. This study is a quasiexperimental research using Type Between Group Design with Posttest Only Design. The number of population was 44 students consit of two classes, and all member of population used to sample study. By using simple random sampling obtained two classes of experiments. Data were analyzed using descriptive statistical and than with count the average of data, obtained scaling data and than hypothesis was tested using t-test analysis with SPSS version 20 for Windows. The results showed there was no significant difference about attitude learning outcome between the group the of students using NHT cooperative learning model and group of students using STAD cooperative learning model in all indicators of attitude that gained $t_{\text {count }} \leq t_{\text {table }}(p>0.05)$.

Key words: $\quad$ NHT cooperative learning model, STAD, model, student's attitude, learning outcome.

\section{PENDAHULUAN}

Tujuan pembelajaran Biologi ditingkat Sekolah Menengah Atas (SMA) antara lain untuk: (1) memupuk sikap ilmiah peserta didik yaitu jujur, objektif, terbuka, ulet, kritis dan dapat bekerja sama dengan orang lain, (2) mengembangkan pengalaman untuk dapat mengajukan dan menguji hipotesis melalui percobaan, serta mengkomunikasikan hasil percobaan secara lisan dan tertulis, (3) mengembangkan kemampuan berpikir analitis, induktif, dan deduktif dengan menggunakan konsep dan prinsip biologi, (4) mengembangkan penguasaan konsep dan prinsip biologi dan saling keterkaitannya dengan IPA lainnya serta mengembangkan pengetahuan, keterampilan dan sikap percaya diri, dan (5) meningkatkan kesadaran dan berperan serta dalam menjaga kelestarian lingkungan (BSNP, 2006). Berdasarkan pada uraian tersebut maka penyelenggaraan pembelajaran biologi dimaksudkan untuk melatih peserta didik agar mampu mengembangkan sikap ilmiah melalui pelibatan peserta didik secara aktif yakni dengan mengekplorasi pengetahuan yang berkaitan dengan alam dan lingkungan sekitar melalui kegiatan-kegiatan sains antara lain melalui menyusun hipotesis, membuktikan hipotesis dengan percobaan, dan mengkomunikasikan hasil percobaan dengan lisan. Pengembangan keterampilan peserta didik melalui kegiatan bekerja secara bersama-sama dengan orang lain dalam mengembangkan kemampuan berpikir dari pola pengetahuan umum ke pola pengetahuan khusus maupun sebaliknya berkaitan dengan pengetahuan alam dan lingkungan sekitar juga dilatihkan melalui pembelajaran Biologi. Dengan demikian, model pembelajaran kooperatif merupakan salah satu model yang tepat untuk diterapkan dalam rangka merealisasikan tujuan pembelajaran biologi tersebut 
Pembelajaran kooperatif pada intinya adalah pembelajaran dengan mengkondisikan peserta didik untuk belajar kelompok agar peserta didik dapat bekerjasama dengan kemampuan maksimal yang mereka miliki dan mempelajari satu dengan yang lain dalam kelompok tersebut. Inti dari pembelajaran kooperatif adalah peserta didik duduk bersama dan bekerja sama di dalam kelompok yang beranggotakan empat orang untuk menguasai materi dan menyelesaikan pekerjaan (Slavin, 2005). Demikian juga yang dinyatakan oleh Sanjaya (2008) bahwa dalam model pembelajaran kooperatif, rangkaian kegiatan belajar dilakukan oleh peserta didik berdasarkan kerja kelompok guna mencapai tujuan pembelajaran yang dirumuskan. Berdasarkan pada beberapa pendapat tersebut dapat disimpulkan bahwa inti dari model pembelajaran kooperatif adalah pengkondisian peserta didik dalam kelompokkelompok kecil agar mereka saling bersinergi dan bekerja sama di dalam kelompoknya didalam menguasai suatu materi atau memecahkan permasalahan-permasalahan dalam rangka mencapai tujuan pembelajaran. Mengkondisikan peserta didik dalam kelompok-kelompok kecil dimaksudkan untuk mendorong peserta didik agar saling membatu antar anggota kelompok dalam rangka mencapai tujuan pembelajaran yang ditetapkan.

Sanjaya (2008) mengemukakan bahwa ada empat unsur penting dalam pembelajaran koperatif, yaitu: (1) adanya peserta kelompok, (2) adanya aturan kelompok, (3) adanya upaya belajar dari setiap kelompok, dan (4) adanya tujuan yang akan dicapai. Sementara itu, Lie (2002) berpendapat bahwa sebuah kerja kelompok dinyatakan sebagai pembelajaran kooperatif apabila terdapat unsur-unsur model pembelajaran gotong royong yang diterapkan, yaitu: (1) saling ketergantungan positif antar anggota kelompok, (2) tanggung jawab perseorangan anggota kelompok, (3) adanya tatap muka, (4) komunikasi antar anggota, dan (5) evaluasi proses kelompok. Dari beberapa pendapat tersebut dapat disimpulkan bahwa unsur-unsur terpenting dalam pembelajaran kooperatif adalah: (1) terbentuknya kelompok belajar dimana setiap peserta didik bertanggungjawab atas segala sesuatu di dalam kelompoknya, seperti halnya mereka bertanggungjawab terhadap mereka sendiri, (2) adanya tugas dan tujuan yang mejadi sebuah aturan kerja kelompok, (3) adanya pelaksanaan tugas yang diemban oleh setiap peserta didik dan juga sebagai bentuk tanggung jawab bersama di antara anggota kelompoknya, oleh karena itu peserta didik haruslah melihat bahwa semua anggota di dalam kelompoknya memiliki tujuan bersama, (4) adanya kerjasama dalam kelompok yang dijadikan sebagai sarana komunikasi yang efektif, oleh karena itu setiap peserta didik perlu berbagi kepemimpinan dan mereka membutuhkan ketrampilan untuk belajar bersama selama proses pembelajaran (5) adanya evaluasi yang akan diminta untuk dipertanggungjawabkan baik secara individual mapun secara kelompok.

Ada beberapa model pembelajaran kooperatif, diantaranya adalah model pembelajaran kooperatif tipe NHT (Numbered Heads Together) dan tipe STAD (Student Teams Achievment Division). Pembelajaran kooperatif tipe NHT merupakan salah satu tipe pembelajaran kooperatif yang menekankan pada struktur khusus yang dirancang untuk mempengaruhi pola interaksi peserta didik dan memiliki tujuan untuk meningkatkan penguasaan akademik. Model pembelajaran kooperatif NHT dikembangkan oleh Kagan dengan melibatkan para peserta didik dalam menelaah bahan yang tercakup dalam suatu pelajaran dan mengecek pemahaman mereka terhadap isi pelajaran tersebut (Ibrahim, 2000). Pembelajaran kooperatif tipe STAD merupakan model pembelajaran yang menekankan pada aktivitas peserta didik belajar dengan cara membentuk kelompok dengan anggota 4 (empat) orang secara heterogen, setelah guru memberikan tugas kepada kelompok setiap anggota kelompok akan berusaha mempelajarinya dan yang sudah bisa memahami materi membantu anggota yang lain (Ibrahim, 2000). Keunggulan pembelajaran tipe STAD ini adalah adanya kerjasama dalam kelompok dan dalam menentukan keberhasilan kelompok tergantung keberhasilan individu. Pembelajaran kooperatif tipe STAD menekankan pada aktivitas dan interaksi diantara peserta didik untuk saling memotivasi dan saling membantu dalam menguasai materi pelajaran guna mencapai prestasi yang maksimal (Isjoni, 2010).

Dalam proses pembelajaran, guru melakukan penilaian terhadap hasil belajar peserta didik dengan menggunakan alat evaluasi berbentuk instrumen. Sudaryono (2012) mengemukakan bahwa evaluasi terhadap hasil belajar yang dicapai oleh peserta didik merupakan penilaian terhadap hasil belajar atau proses belajar tersebut, untuk mengetahui sejauh mana hasil belajar dan proses pembelajarannya dapat dinilai baik. Sudijono (2012) memberikan pengertian terhadap evaluasi hasil belajar merupakan rangkaian kegiatan yang ditujukan untuk memperoleh informasi ketercapaian tujuan pembelajaran yang telah ditentukan sebelumnya, sehingga informasi tersebut dapat dijadikan sebagai umpan balik penyempurnaan program pembelajaran. Berdasarkan definisi-definisi tersebut, dapat disimpulkan bahwa penilaian hasil belajar peserta didik merupakan tindakan untuk mengumpulkan informasi tentang tingkat penguasaan terhadap tujuan-tujuan khusus dan tujuan-tujuan umum dalam pembelajaran yang dicapai oleh peserta didik, selanjutnya informasi tersebut dijadikan sebagai media untuk melakukan kegiatan monitoring atau diagnosis terhadap program-program pembelajaran.

Djaali \& Pudjiono (2008) menyebutkan bahwa objek-objek penilaian hasil belajar peserta didik meliputi: (1) prestasi peserta didik yang dapat diukur dengan menggunakan instrument tes, (2) sikap peserta 
didik yang dapat diukur dengan menggunakan skala sikap, (3) motivasi peserta didik yang dapat diukur dengan instrument yang dikembangkan dari berbagai teori motivasi, (4) intelegensia peserta didik yang dapat dikukur dengan tes intelegensia, (5) bakat peserta didik yang dapat diukur dengan menggunakan tes bakat, (6) kecerdasan emosional, (7) minat peserta didik, dan (8) kepribadian peserta didik. Sementara itu Winkel (2009) menyatakan bahwa ranah penilaian hasil belajar meliputi: (1) ranah kognitif, yaitu evaluasi terhadap kegiatan-kegiatan yang menyangkut aktivitas pemahaman peserta didik, (2) ranah afektif, yaitu evaluasi berkaitan dengan sikap atau penilaian peserta didik setelah memiliki penguasaan kognitif, dan (3) ranah psikomotor, yaitu evaluasi terhadap kemampuan atau keterampilan peserta didik dalam bertindak setelah menerima pengalaman belajar tertentu. Sementara itu, Sudijono (2012) menyatakan bahwa prinsip yang perlu dipegang dalam rangka melaksanakan evaluasi hasil belajar peserta didik adalah prinsip kebulatan, yaitu guru dituntut untuk melakukan evaluasi secara menyeluruh terhadap pemahaman, sikap dan keterampilan peserta didik.

Lingkup objek penilaian hasil belajar berpedoman pada beberapa pendapat yang disebut merupakan penilaian terhadap hasil belajar setelah peserta didik melaksanakan proses pembelajaran, yang bersifat menyeluruh terhadap ranah-ranah objek evaluasi hasil belajar yang meliputi: (1) ranah pemahaman peserta didik, (2) ranah sikap peserta didik, dan (3) ranah keterampilan peserta didik.

Penilaian hasil belajar peserta didik dalam ranah sikap, oleh Krathwohl (dikutip dalam Sudijono, 2012) meliputi: (1) receiving (penerimaan), (2) responding (pemberian respon), (3) valuing (penilaian atau penentuan sikap), (4) organization (pengorganisasian), dan (5) characterization by a value or value complex (karakterisasi/pembentukan pola hidup). Penerimaan mengacu kepada kemampuan memperhatikan dan memberikan respon terhadap stimulasi yang tepat. Penerimaan merupakan tingkat hasil belajar terendah dalam domain afektif. Pemberian respon atau partisipasi, merupakan satu tingkat di atas penerimaan, dalam hal ini peserta didik menjadi terlibat secara afektif, menjadi peserta dan tertarik. Penilaian atau penentuan sikap mengacu kepada nilai atau pentingnya menterikatkan diri pada objek atau kejadian tertentu dengan reaksi-reaksi seperti menerima, menolak atau tidak menghiraukan. Organisasi mengacu kepada penyatuan nilai, sikap-sikap yang berbeda yang membuat lebih konsisten dapat menimbulkan konflikkonflik internal dan membentuk suatu sistem nilai internal, mencakup tingkah laku yang tercermin dalam suatu filsafat hidup. Karakterisasi/pembentukan pola hidup mengacu kepada karakter dan daya hidup sesorang yang ada hubungannya dengan keteraturan pribadi, sosial dan emosi jiwa.

Beberapa penelitian yang berkaitan dengan efektivitas model pembelajaran kooperatif terhadap hasil belajar bilogi peserta didik telah dilakukan sebelumnya. Jufri \& Jekti (2010) melakukan penelitian dengan menerapkan pembelajaran kooperatif tipe STAD dan TGT (Team Games Turnament) yang dipadukan dengan perangkat Pembelajaran Sains Berbasis Inkuiri (PSBI) pada pembelajaran IPA Biologi SMP. Hasil penelitian menunjukan bahwa kelompok peserta didik yang memperoleh perlakuan pembelajaran IPA Biologi dengan perangkat PSBITAD maupun PSBI-TGT lebih unggul dalam hal keterampilan berpikir kritis dibandingkan kelompok peserta didik yang memperoleh perlakuan NonPSBISTAD maupun NonPSBI-TGT.

Muraya \& Kimamo (2011) meneliti tentang pengaruh pembelajaran kooperatif tipe STAD terhadap nilai rata-rata hasil belajar Biologi peserta didik dengan mempertimbangkan jenis kelamin peserta didik. Hasil penelitian menunjukkan bahwa terdapat pengaruh yang signifikan terhadap nilai rata-rata hasil belajar biologi peserta didik, kelompok peserta didik yang mendapatkan perlakuan model pembelajaran kooperatif tipe STAD memiliki nilai rata-rata Biologi yang lebih tinggi, namun tidak terdapat perbedaan nilai rata-rata Biologi antara kelompok peserta didik laki-laki dan kelompok peserta didik perempuan setelah mendapatkan perlakuan pembelajaran kooperatif tipe STAD. Achruddin, dkk (2013) melakukan penelitian dengan menerapkan model pembelajaran tipe STAD dibantu dengan media video dalam rangka meningkatkan aktivitas sosial peserta didik dalam pembelajaran Biologi. Hasil penelitian menunjukkan bahwa pembelajaran tipe STAD dibantu dengan media video berpengaruh secara signifikan terhadap peningkatan aktivitas sosial peserta didik. Muldayanti (2013) melakukan penelitian untuk mengetahui pengaruh penerapan pembelajaran TGT dan STAD terhadap prestasi belajar Biologi peserta didik dengan mempertimbangkan keingintahuan dan minat peserta didik. Hasil penelitian menunjukkan bahwa ada pengaruh penggunaan metode pembelajaran dengan TGT dan STAD terhadap prestasi belajar Biologi, dan terdapat interaksi antara metode pembelajaran, keingintahuan tinggi dan rendah, minat belajar tinggi dan rendah terhadap prestasi belajar Biologi.

Berdasarkan pada penjelasan di atas, sasaran pembahasan masalah pada penelitian ini adalah untuk mengetahui pengaruh penerapan model pembelajaran kooperatif tipe NHT dan tipe STAD terhadap hasil belajar sikap peserta didik pada indikator: rasa ingin tahu, tanggungjawab, dan disiplin.

\section{METODOLOGI}

Metode yang digunakan dalam penelitian ini adalah metode kuasi eksperimen dan metode deskriptif. Metode kuasi eksperimen digunakan untuk memperoleh gambaran pengaruh model pembelajaran NHT dan model pembelajaran STAD terhadap hasil belajar peserta didik. Metode deskriptif diterapkan untuk memperoleh gambaran sikap peserta didik 
sebagai dampak dari penerapan model pembalajaran NHT dan model pembelajaran STAD pada penyampaian materi sistem pencernaan. Desain penelitian yang digunakan adalah Type Between Group Design dengan Posttest Only Design (Creswell, 2012).

Populasi dalam penelitian ini adalah peserta didik kelas XI SMA Negeri 2 Gerung peminatan IPA yang terdiri atas dua kelas dengan jumlah peserta didik 44 orang. Sampel penelitian dipilih dari keseluruhan populaasi, sedangkan pemilihan kelas eksperimeh digunakan teknik simple random sampling. Dengan menggunakan simple random sampling diperoleh satu kelas untuk diberikan perlakuan model pembelajaran kooperatif tipe NHT dilanjutkan dengan tipe STAD, dan satu kelas untuk diberikan perlakuan model pembelajaran kooperatif tipe STAD dilajutkan dengan tipe NHT.

Tahap-tahap dalam penelitian ini meliputi tahap persiapan, tahap pelaksanaan, dan tahap analisis hasil penelitian.

1. Tahap Persiapan

Penelitian dimulai dengan mengkaji konsepkonsep dalam kurikulum Biologi untuk SMA (kurikulum 2013), melakukan studi pendahuluan, melakukan analisis materi sistem pencernaan, mengkaji penelitian-penelitian yang sudah dilaksanakan sebelumnya yaitu penelitian-penelitian yang berkaitan dengan penerapan model kooperatif pada pembelajaran Biologi, dan menyusun perangkat-prangkat pembelajaran yang meliputi: Rencana Pelaksanaan Pembelajaran (RPP), Lembar Kerja Peserta Didik (LKPD), instrumen tes sikap, dan instrumen observasi keterlaksanaan model pembelajaran koperatif.
Perangkat-perangkat penelitian selanjutnya divalidasi oleh para ahli. Sementara itu, instrumen tes pemahaman dan tes keterampilan diujicoba pada kelompok peserta didik yang telah memperoleh materi sistem pencernaan selanjutnya dilakukan analisis hasil ujicoba. Masukan-masukan dari hasil validasi ahli selanjutnya digunakan untuk merevisi dan menyempurnakan perangkat-perangkat penelitian.

2. Tahap Pelaksanaan Penelitian

Tahap ini merupakan tahap penerapan perangkat-perangkat pembelajaran yang telah divalidasi oleh para ahli, telah diujicoba, dan telah dilakukan penyempurnaan berdasarkan masukan para ahli dan hasil analisis ujicoba. Tahap pelaksanaan meliputi:

a. Pelaksanaan pretest pengetahuan sistem pencernaan pada kedua kelas perlakuan. Hasil pretest pengetahuan dipergunakan sebagai data kovarian pada tahap analisis data penelitian.

b. Penyampaian materi sistem pencernaan terdiri dari: 1) Zat Makanan; 2) Body Mass Index (BMI) dan Basal Metalic Rate (BMR); 3) Menu Makanan Sehat; 4) Struktur dan Fungsi Sel Penyusun Jaringan Sistem Pencernaan makanan manusia; 5) Struktur Jaringan Sistem Pencernaan Ruminansia dan 6) Penyakit dan Gangguan Bioproses. Penyampaian materi sistem pencernaan menerapkan model pembelajaran NHT dan STAD secara bergantian dengan urutan yang berbeda pada setiap kelas perlakuan. Adapun rincian penerapan model pembelajaran NHT dan STAD pada setiap materi sistem pencernaan dicantumkan dalam Tabel 1.

Tabel 1.Penerapan Model Pembelajaran NHT dan STAD pada Materi Sistem Pencernaan

\begin{tabular}{lcc}
\hline Materi & \multicolumn{2}{c}{ Model Pembelajaran Kooperatif } \\
\cline { 2 - 3 } & Kelas Eksperimen I & Kelas Eksperimen II \\
\hline Zat Makanan & NHT & STAD \\
Body Mass Index (BMI) dan Basal & STAD & NHT \\
$\begin{array}{l}\text { Metalic Rate (BMR) Makanan Sehat } \\
\text { Struktur dan Fungsi Sel Penyusun }\end{array}$ & NHT & STAD \\
Jaringan Sistem Pencernaan makanan & & \\
manusia & STAD & NHT \\
Struktur Jaringan Sistem Pencernaan & & \\
Ruminansia & NHT & STAD \\
Penyakit dan Gangguan Bioproses & STAD & NHT \\
\hline
\end{tabular}

c. Pelaksanaan observasi keterlaksanaan model pembelajaran NHT dan model pembelajaran STAD.

d. Pengamatan sikap peserta didik pada setiap proses pembelajaran pada kedua kelas perlakuan yang meliputi indikator sikap: rasa ingin tahu, tanggungjawab, dan disiplin.

3. Tahap Analisis Data

Data hasil belajar sikap siswa berbentuk data kualitatif yang diperoleh melalui angket selanjutnya dikonversikan dalam bentuk data kuantitatif berdasarkan tanggapan responden dengan ketentuan pilihan jawaban: Sangat Setuju (SS) memperoleh skor 4, Setuju (S) memperoleh skor 3, Tidak Setuju (TS) memperoleh skor 2, dan Sangat Tidak Setuju (STS) memperoleh skor 1. Data diolah menggunakan statistik deskriptif yaitu dengan menghitung rata-rata dari jawaban yang diberikan kemudian dinyatakan dalam bentuk persentase dari setiap pernyataan (Gunawan, 2010). 
Data persentase selanjutnya diuji hipotesisnya dengan menggunakan uji parametrik uji perbedaan rata-rata (uji-t) jika sebaran data memenuhi uji prasyarat analisis. Pengujian hipotesis didasarkan pada $t_{\text {hitung }}$ yang dikonsultasikan dengan $t_{\text {tabel }}$ pada taraf signifikasi $(\alpha) 0,05$. Kriteria pengujian adalah:

\section{HASIL PENELITIAN}

Data hasil belajar sikap diperoleh melalui pengamatan sikap peserta didik selama proses pembelajaran biologi sistem pencernaaan dengan penerapan model pembelajaran kooperatif NHT dan STAD. Lembar observasi sikap peserta didik jika diperoleh nilai $t_{\text {hitung }} \leq t_{\text {tabel }}$ maka $\mathrm{H}_{0}$ diterima, sedangkan jika diperoleh nilai $t_{\text {tabel }}<t_{\text {hitung }}$ maka $\mathrm{H}_{0}$ ditolak (Kadir, 2010). Pengujian dilakukan dengan bantuan program SPSS versi 20 for Windows.

mencakup pengamatan terhadap tiga sikap yang meliputi: rasa ingin tahu, tanggung jawab, dan disiplin. Nilai sikap peserta didik dicantumkan dalam Tabel 4.4. Nilai tersebut merupakan gambaran nilai rata-rata terhadap tiga indikator sikap dari pengamatan sikap peserta didik dalam setiap materi pembelajaran baik pada kelas NHT maupun kelas STAD.

Tabel 1. Deskripsi Data Hasil Belajar Sikap Peserta Didik Pada Materi Sistem Pencernaan

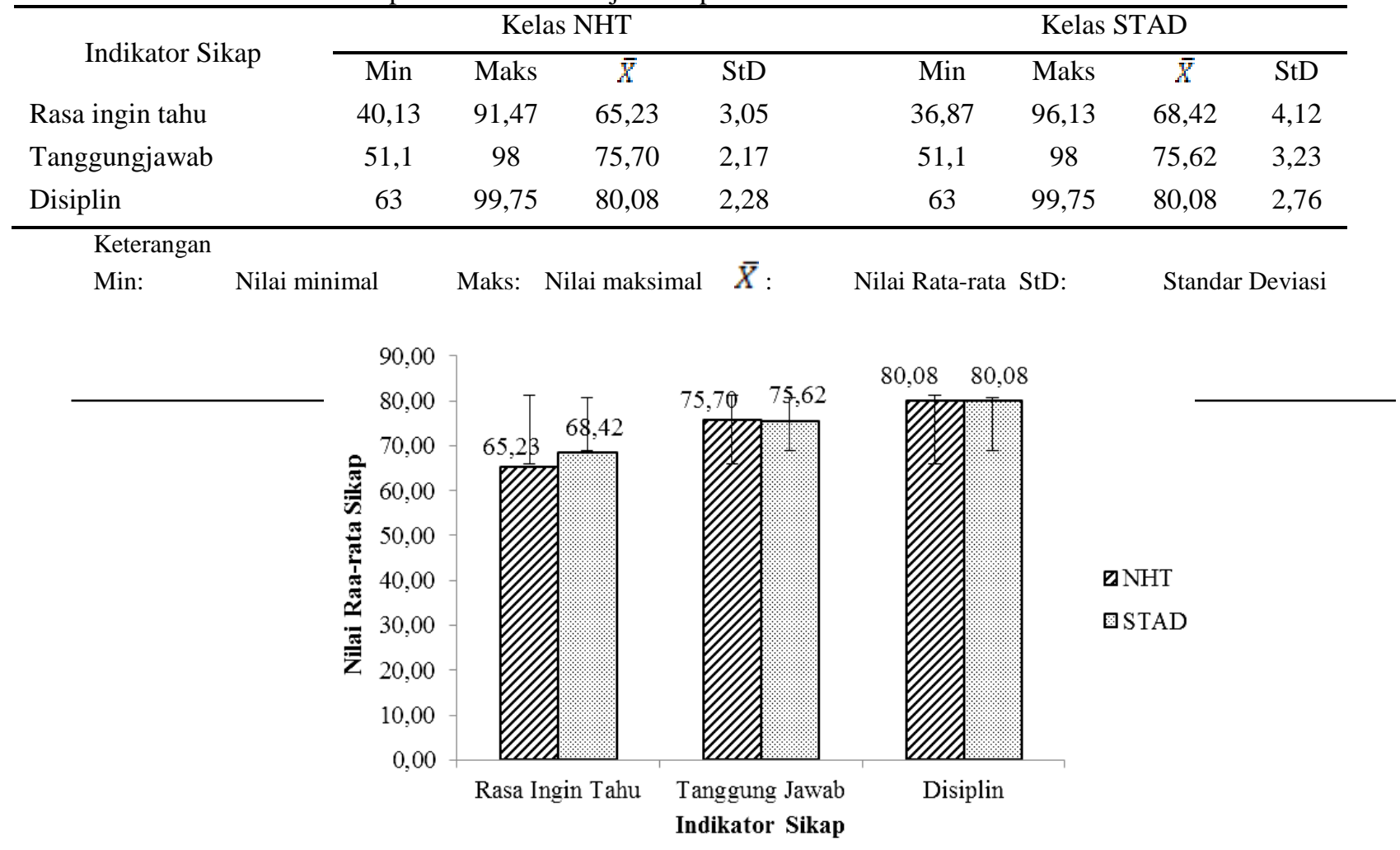

Gambar 1. Diagram perbandingan data hasil belajar sikap untuk setiap indikator sikap.

Uji prasyarat analisis meliputi dari uji normalitas data dan uji homogenitas varians terhadap data hasil belajar sikap peserta didik. Uji normalitas menggunakan uji Kolmogorov Smirnov, dengan bantuan program SPSS 20 for Windows. Hasil uji normalitas data ditampilkan dalam Tabel 2.

Tabel 2. Hasil Uji Normalitas Data Hasil Belajar Sikap Peserta Didik

\begin{tabular}{lcc}
\hline \multicolumn{1}{c}{ Indikator Sikap } & \multicolumn{2}{c}{ Kolmogorov-Smirnov } \\
\cline { 2 - 3 } Rasa Ingin Tahu & 0,44 & $\alpha$ \\
Tanggungjawab & 0,49 & 0,05 \\
Disiplin & 0,11 & 0,05 \\
\hline Keterangan & & 0,05 \\
Sig (p). & $:$ signifikasi hasil pengujian \\
$\alpha \quad: \quad$ taraf signifikasi yang ditentukan &
\end{tabular}


Uji Kolmogorov-Smirnov terhadap data hasil belajar sikap pada setiap indikator sikap menunjukkan bahwa:

a. Pada indikator Rasa Ingin Tahu, diperoleh nilai signifikasi $\quad(p)=0,44>\alpha$, sehingga dapat disimpulkan bahwa data hasil belajar sikap pada indikator Rasa Ingin Tahu berdistribusi normal.

b. Pada indikator Tanggungjawab, diperoleh nilai signifikasi $\quad(p)=0,19>\alpha, \quad$ sehingga dapat disimpulkan bahwa data hasil belajar sikap pada indikator Tanggungjawab berdistribusi normal.

c. Pada materi Displin, diperoleh nilai signifikasi $(p)=0,11>\alpha$, sehingga dapat disimpulkan bahwa data hasil belajar sikap pada indikator Disiplin berdistribusi normal.

Uji homogenitas varians menggunakan uji Levene dengan bantuan program SPSS 20 for Windows. Hasil uji homogenitas varians ditampilkan dalam Tabel 3.

Tabel 3. Hasil Uji Homogenitas Varian Data Hasil Belajar Sikap Peserta Didik

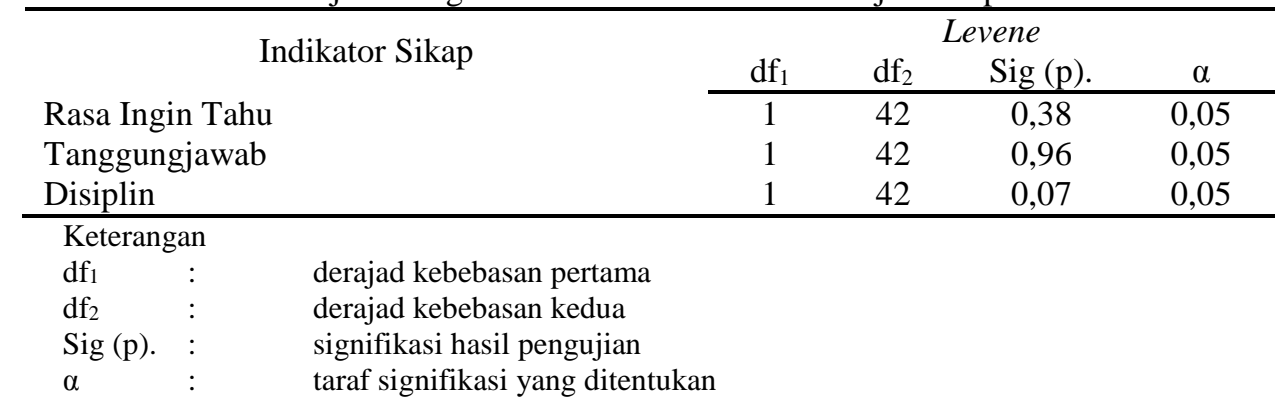

Uji Levene terhadap data hasil belajar sikap pada setiap indikator sikap menunjukkan bahwa:

a. Pada materi Rasa Ingin Tahu, diperoleh nilai signifikasi $(p)=0,31>\alpha$ pada $\mathrm{df}_{1}=1$ dan $\mathrm{df}_{2}=42$, sehingga dapat disimpulkan bahwa data hasil belajar sikap pada indikator Rasa Ingin Tahu memiliki varian yang homogen.

b. Pada materi Tanggungjawab, diperoleh nilai signifikasi $(p)=0,79>\alpha$ pada $\mathrm{df}_{1}=1$ dan $\mathrm{df}_{2}=42$, sehingga dapat disimpulkan bahwa data hasil belajar sikap pada indikator Tanggungjawab memiliki varian yang homogen. c. Pada materi Displin, diperoleh nilai signifikasi $(\mathrm{p})=0,48>\alpha$ pada $\mathrm{df}_{1}=1$ dan $\mathrm{df}_{2}=42$, sehingga dapat disimpulkan bahwa data hasil belajar sikap pada indikator Disiplin memiliki varian yang homogen.

Uji hipotesis dilakukan dengan teknik statistik uji perbandingan rata-rata menggunakan uji-t (Independent-Samples $T$ Test), dengan bantuan program SPSS 20 for windows. Hasil analisis statistik uji hipotesis dicantumkan dalam Tabel 4.

Tabel 4. Hasil Uji-t untuk Data Hasil Belajar Sikap.

\begin{tabular}{lccccc}
\hline \multirow{2}{*}{ Indikator Sikap } & \multicolumn{5}{c}{ Uji $t$} \\
\\
Rasa Ingin Tahu & df & Sig $(\mathrm{p})$. & $\alpha$ & $\mathrm{t}_{\text {hitung }}$ & $\mathrm{t}_{\text {tabel }}$ \\
\hline Tanggungjawab & 42 & 0,38 & 0,05 & 0,88 & 2,02 \\
Disiplin & 42 & 0,96 & 0,05 & 0,06 & 2,02 \\
\hline
\end{tabular}

Keterangan
df $\quad:$
Sig $(\mathrm{p}) . \quad:$
$\alpha \quad:$
thitung $\quad:_{\text {tabel }} \quad:$

Hasil uji t terhadap data hasil belajar sikap pada setiap indikator menunjukkan bahwa:

a. Pada materi Rasa Ingin Tahu, diperoleh nilai signifikasi $(\mathrm{p})=0,44>\alpha$ pada $\mathrm{df}=42$ dengan $t_{\text {hitung }}(0,88) \leq t_{\text {tabel }}(2,02)$. Sesuai dengan hasil analisis statistik dapat disimpulkan bahwa data hasil belajar sikap pada indikator Rasa Ingin Tahu tidak berbeda secara signifikan antara kelompok siswa kelas NHT dengan kelompok siswa kelas STAD. derajad kebebasan signifikasi hasil pengujian nilai thasil perhitungan nilai t sesuai tabel pada derajad kebebasan yang ditentukan b. Pada materi Tanggungjawab, diperoleh nilai signifikasi $(p)=0,19>\alpha$ pada $d f=44$ dengan $t_{\text {hitung }}(0,06) \leq t_{\text {tabel }}(2,02)$. Sesuai dengan hasil analisis statistik dapat disimpulkan bahwa data hasil belajar sikap pada indikator Tanggungjawab tidak berbeda secara signifikan antara kelompok siswa kelas NHT dengan kelompok siswa kelas STAD.

c. Pada materi Displin, diperoleh nilai signifikasi $(\mathrm{p})=0,11>\alpha \quad$ pada $\quad \mathrm{df}=42$ dengan $\mathrm{t}_{\text {hitung }}(-$ $1,85) \leq \mathrm{t}_{\text {tabel }}(2,02)$. Sesuai dengan hasil analisis 
statistik dapat disimpulkan bahwa data hasil belajar sikap pada indikator Disiplin tidak berbeda secara signifikan antara kelompok siswa kelas NHT dengan kelompok siswa kelas STAD.

\section{PEMBAHASAN}

Pengamatan terhadap sikap peserta didik dalam penelitian ini difokuskan pada tiga indikator sikap yaitu: rasa ingin tahu, tanggungjawab, dan disiplin. Hipotesis awal yang dikemukaan peneliti adalah sikap yang muncul sebagai dampak pengiring proses pembelajaran kooperatif tidak akan berbeda secara signifikan antara kelompok model pembelajaraan kooperatif NHT dan model pembelajaran kooperatif STAD. Analisis hasil penelitian dengan menggunakan uji-t (Independent-Samples $T$ Test) terhadap sikap peserta didik pada setiap indikator diperoleh nilai $t_{\text {hitung }}$ $\leq \mathfrak{t}_{\text {tabel }}$ pada taraf signifikasi $5 \%$. Indikator rasa ingin tahu, tanggungjawab, dan disiplin tidak berbeda secara signifikan antara kelompok model pembelajaran NHT dan kelompok model pembelajaran kooperatif STAD. Hasil penelitian menunjukkan bahwa rata-rata nilai sikap untuk indikator rasa ingin tahu adalah 65,23 untuk kelompok pembelajaran kooperatif NHT dan 68,42 untuk kelompok pembelajaran kooperatif STAD. Untuk indikator tanggungjawab, diperoleh nilai ratarata 75,70 untuk kelompok pembelajaran kooperatif NHT dan 75,62 untuk kelompok pembelajaran kooperatif STAD. Sedangkan untuk indikator disiplin, diperoleh nilai rata-rata yang sama sebesar 80,08 untuk kelompok pembelajaran kooperatif NHT dan kelompok pembelajaran kooperatif STAD.

Prinsip dasar dari pembelajaran kooperatif adalah menciptakan situasi dimana keberhasilan individu ditentukan atau dipengaruhi oleh keberhasilan kelompoknya. Oleh karena itu, karaktersitik pembelajaran kooperatif diwarnai dengan berbagai macam tujuan sikap sosial antara lain penerimaan terhadap orang yang berbeda ras, budaya, kelas sosial, maupun kemampuan. Ibrahim, dkk (2000) mengemukakan bahwa pembelajaran kooperatif memungkinkan siswa yang berbeda latar belakang dan kondisi untuk bekerja saling bergantung satu dengan yang lain atas tugas-tugas bersama, dan melalui penggunaan struktur penghargaan kooperatif, belajar untuk menghargai satu dengan yang lain.

Dalam pembelajaran kooperatif keterampilan sikap merupakan hal yang penting untuk diajarkan. Keterampilan sikap merupakan salah satu unsur penunjang bagi keberhasilan pekerjaan orang dewasa yang sebagian besar dilakukan dalam organisasi yang saling bergantung satu sama lain. Atas dasar itu, keterampilan sikap merupakan hal yang penting untuk diamati dalam proses penerapan pembelajaran kooperatif. Ibrahim, dkk (2000) mengemukakan bahwa tujuan penting yang lain dari pembalajaran kooperatif adalah untuk mengajarkan kepada siswa keterampilan sikap displin, sikap tanggungjawab, dan sikap kerjasama dari masing-masing individu untuk keberhasilan kelompok sesuai degan tujuan pembelajaran.

Hasil penelitian ini sejalan dengan penelitian yang telah dilakukan oleh Mantara, dkk (2013) yang meneliti tentang pengaruh pembelajaran kooperatif STAD berbantuan penilaian kinerja dengan menempatkan faktor sikap sebagai variabel kovarian. Hasil penelitian menunjukkan bahwa rata-rata skor sikap pada kelompok siswa yang memperoleh perlakuan pembelajaran kooperatif STAD mengungguli kelompok konvensional. Hasil penelitian yang sama juga telah dilakukan oleh Darmini, dkk (2013) dimana sikap sosial siswa yang mengikuti pembelajaran kooperatif tehnik STAD secara signifikan lebih baik daripada siswa yang mengikuti pembelajaran konvensional.

\section{KESIMPULAN}

Pemberikan perlakuan model pembelajaran yang berbeda antara kelompok siswa yang diberikan model pembelajaran kooperatif NHT dengan model pembelajaran kooperatif STAD tidak berpengaruh terhadap hasil belajar sikap siswa untuk indikator: rasa ingin tahu, tanggungjawab, dan disiplin.

\section{DAFTAR PUSTAKA}

[1] Achruddin, Sajidan, \& Indrowati, M. 2013. Peningkatan Aktivitas Sosial Siswa dalam Pembelajaran Biologi melalui Penerapan Model Pembelajaran STAD disertai Video di Kelas VII SMP Negeri 1 Jaten. Jurnal Pendidikan Biologi FKIP UNS. Volume 5, No. 1 .

[2] BSNP Depdiknas. 2006. Kurikulum 2006 SMK (KTSP) Pedoman Khusus Pengembangan Silabus dan Penilaian Mata Pelajaran Fisika. Jakarta: Departemen Pendidikan Nasional.

[3] Creswell, J.W. 2012. Educational Research. Planning, Conducting, and Evaluating Quantitative and Qualitative Research. Boston: Pearson Education, Inc.

[4] Darmini, N. N, Lasmawan, W., \& Dantes, N. 2013. Pengaruh Model Pembelajaran Kooperatif Tehnik STAD Terhadap Hasil Belajar Dilihat dari Sikap Sosial Siswa dalam Pembelajaran IPS. e-Journal Program Pascasarjana Universitas Pendidikan Ganesha Jurusan Pendidikan Dasar, Volume 3 Tahun 2011.

[5] Djaali \& Pudjiono. 2008. Pengukuran Dalam Bidang Pendidikan. Jakarta: Grasindo. 
[6] Gunawan. 2010. "Pengembangan Model Virtual Laboratory Fisika Modern Untuk Meningkatkan Keterampilan Generik Sains dan Disposisi Berpikir Kritis Calon Guru". Disertasi Universitas Pendidikan Indonesia, tidak dipublikasikan.

[7] Ibrahim, M., Rachmadiati, F., Nur, M., \& Ismono. 2000. Pembelajaran Kooperatif. UNESA Surabaya: University Press.

[8] Isjoni. H. 2010. Pembelajaran Koopertaif Meningkatkan Kecerdasan Komunikasi Antar Peserta Didik. Yogyakarta: Pustaka Pelajar.

[9] Jufri, A. W. Dan Jekti, D.S.D. 2010. Efektifitas Pembelajaran Sains Berbasis Inkuiri dengan Strategi Kooperatif dalam Meningkatkan Keterampilan Berpikir Kritis Siswa SMP. Jurnal Pendidikandan Pembelajaran Volume17 Nomor 2 hal 159-165.

[10] Kadir. 2010. Statistik Untuk Penelitian dan Ilmuilmu Sosial. Jakarta: Rosemata Sampurna.

[11] Muldayanti. 2013. Pembelajaran Biologi Model STAD dan TGT Ditinjau dari Keingintahuan

\section{Dan Minat Belajar Siswa. Jurnal Pendidikn IPA Indonesia (JPII) Volume (2) 1, April 2013, Halaman 12-17.}

[12] Muraya, D. N., \& Kimamo, G. 2011. Effects of Cooperative Learning Approach on Biology Mean Achievement Scores of Secondary School Students' in Machakos District,
Kenya. Educational Research and Reviews Vol. 6(12), pp. 726-745, 25 September, 2011 ISSN 1990-3839.

[13] Lie, A. 2007. Cooperative Learning. Jakarta : Grasindo.

[14] Mantara, B., Koyan, I. W., \& Natajaya, N. 2013. Pengaruh Model Pembelajaran Kooperatif Tipe Student Teams Achievement Division (STAD) Berbantuan Asesmen Kinerja Terhadap Prestasi Belajar Kewirausahaan Dikendalikan oleh Sikap pada Pelajaran Kewirausahaan Siswa Kelas X TGB SMKN 3 Singaraja. e-Journal Program Pascasarjana Universitas Pendidikan Ganesha Program Studi Penelitian dan Evaluasi Pendidikan Volume 3 Tahun 2013.

[15] Sanjaya, W. 2008. Strategi Pembelajaran. Jakarta: Kencana Prenada Media Group

[16] Slavin, R.E. 2005. Cooperative Learning. Theory, Research and Practice. Narulita Yusron. (penerjemah). (2008). Bandung: Nusa Media.

[17] Sudaryono. 2012. Dasar-dasar Evaluasi Pembelaran. Yogyakarta:Graha Ilmu

[18] Sudijono. 2012. Pengantar Evaluasi Pendidikan. Jakarta: Grafindo Persada

[19] Winkel, W.S. 2009. Psikologi Pengajaran. Yogyakarta: Media Abadi 